\title{
Coupled Effect of temperature and additions on the rheological behavior of concrete equivalent mortars (CEM)
}

\author{
El Hadja Dada ${ }^{1, *}$, Akram Salah-Eddine Belaidi $^{1}$, Hamza Soualhi ${ }^{2}$, El Hadj Kadri ${ }^{3}$ \\ ${ }^{1}$ LRGC Civil Engineering Research Laboratory, University of Laghouat / PO 37G Ghardaia Road, Laghouat Algeria. \\ ${ }^{2}$ L2MGC Civil Engineering Mechanics and Materials Laboratory / 5 Mail Gay-Lussac, Cergy-Pontoise France. \\ ${ }^{3}$ MONTESQUIEU School, Beauchamp. Versailles Academy, France.
}

\begin{abstract}
The aim of this work is to study the influence of mineral additions on the rheological behavior of low impact environmental concrete with its concrete equivalent mortar (CEM) at different temperatures. The experimental study is carried out on cement-based CEM substituted by two additions namely, natural pozzolana (PZ) and marble powder (PM), with a substitution rate of 5 to $20 \%$, a ratio of water on binder E / $\mathrm{L}=0.5$ and a percentage of superplasticizer based on polycarboxylates $\mathrm{SP}=0.30 \%$. The rheological parameters, the workability and the flow time of the mixtures were tested by a coaxial rheometer, a mini cone and the LCPC maniabilitimetre respectively at $10^{\circ} \mathrm{C}, 20^{\circ} \mathrm{C}$ and $30^{\circ} \mathrm{C}$. The results show that the substitution of cement by natural pozzolana and marble powder in binary system generally improved viscosity and yield stress at $20^{\circ} \mathrm{C}$ and $30^{\circ} \mathrm{C}$, while at $10^{\circ} \mathrm{C}$ natural pozzolana negatively affected the rheological parameters and workability
\end{abstract}

\section{Introduction}

Currently, the composition of a concrete mixture must be more environmentally friendly. However, it is essential to reduce the production of cement, the main component of concrete and the most $\mathrm{CO} 2$ emitting component. For this purpose, it is imperative to develop eco-mortars and concretes with low environmental impact in which a part of cement is replaced by mineral additions. During the development of these materials, many parameters must be mastered. Among these parameters, workability and implementation are very important, due to their essential role in the construction process and their influence on the mechanical properties and durability of cured concrete to a certain extent. The mixture rheological properties are in a way a workability quality signature of a mixture. Moreover, being able to qualify and quantify the fresh concrete rheological behavior is an important asset in construction field. This is especially important when attaching special importance to the influence of mineral additions and temperature.

Numerous studies (Belaidi et al [1], Dada et al [2], Cassagnabere et al [3] present cement substitution effect by these mineral additions on workability and their influence on the rheological behavior. Escalante-Garcia et al [4] have confirmed that there are several mechanisms of mineral additions action that induce changes in cement paste rheology or concrete rheology. Several researchers have studied temperature effect of the mortar and concrete rheological behavior, (yamada et al [5], Hanehara and Yamada [6], Ghafoori and Diawara [7] and Cygan et al [8]).
The variation in SP adsorption caused by a change in temperature must therefore influence admixture effectiveness and therefore vary fresh concrete rheological parameters. The aim of this work is to study the mineral additions-temperature coupled effect on low environmental impact concrete rheological behavior of by their concrete equivalent mortars (CEM), mainly based on local materials. and available (natural or from industrial waste) such as natural pozzolana and marble powder and their effects in an ambient temperature of 10 ${ }^{\circ} \mathrm{C}, 20^{\circ} \mathrm{C}$ and $30^{\circ} \mathrm{C}$.

\section{Experimental programs}

\subsection{Materials}

In this study, a cement (CEM I 42.5) and two mineral additives such as natural pozzolana (PZ) and marble powder (MP) were used. Their chemical and physical properties are given in Table 1. As well as the morphology and particle size distribution determined by a scanning electron microscope and a laser scattering technique are shown in Figures 1 and 2 respectively. The sand used is alluvial sand with a maximum grain size of $5 \mathrm{~mm}$ for all mixtures. The physical properties are summarized in Table 2

\footnotetext{
El hadja Dada: elhadjadada71@gmail.com
} 


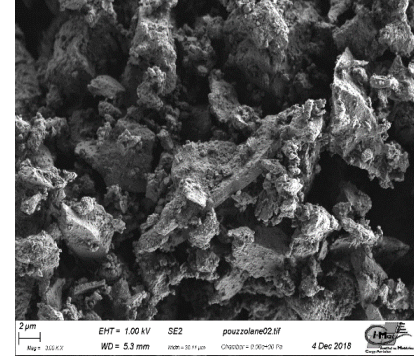

Natural Pouzzolana

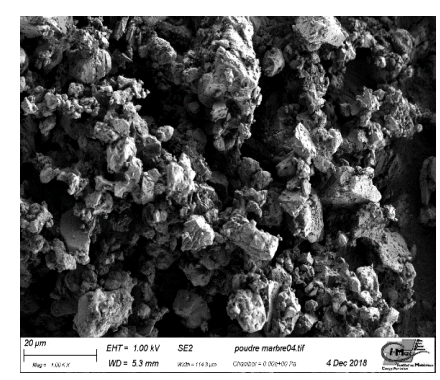

Marble Powder
Fig. 1. Scanning electron microscope analysis.

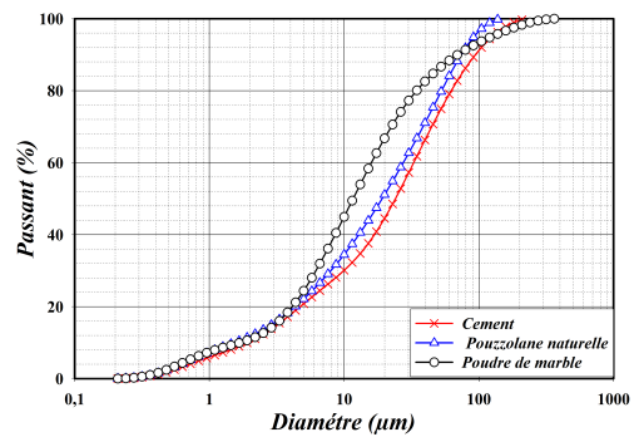

Fig. 2. Particle size distributions of cementitious materials

Table 1. Chemical and physical properties of OPC, PZ et MP.

\begin{tabular}{cccl}
\hline $\begin{array}{l}\text { Chimical } \\
\text { Analysis (\%) }\end{array}$ & $(\mathbf{O P C})$ & $(\mathbf{P Z})$ & $(\mathbf{M P})$ \\
\hline $\mathrm{SiO}_{2}$ & 21 & 41.34 & 0.42 \\
$\mathrm{CaO}$ & 58.70 & 12.90 & 56.01 \\
$\mathrm{Mgo}$ & 1.8 & 3.23 & 0.12 \\
$\mathrm{Al}_{2} \mathrm{O}_{3}$ & 5.35 & 17.18 & 0.13 \\
$\mathrm{Fe}_{2} \mathrm{O}_{3}$ & 4.44 & 9.20 & 0.06 \\
$\mathrm{SO}_{3}$ & 1.88 & 0.02 & 0.01 \\
$\mathrm{~K}_{2} \mathrm{O}$ & 0.60 & 2.17 & 0.01 \\
$\mathrm{TiO}_{2}$ & 0.34 & 1.94 & 0.01 \\
$\mathrm{Na}_{2} \mathrm{O}$ & 0.42 & 2.55 & 0.06 \\
$\mathrm{P}_{2} \mathrm{O}_{5}$ & 0.17 & 0.64 & 0.03 \\
Fire loss & 5.31 & 8.84 & 43.43 \\
Specific density & 3.16 & 2.69 & 2.67 \\
Fineness $\left(\mathrm{cm}^{2} / \mathrm{g}\right)$ & 4000 & 3200 & 2126 \\
\hline
\end{tabular}

A new generation polycarboxylate (SP) high waterreducing superplasticizer was used with a specific weight of 1.07 and a dry extract of $30 \%$ and a $\mathrm{pH}$ of 6.5 .

\subsection{Mixing Proportions}

The CEM formulation was deduced directly from the composition of an initial concrete formulated with a cement dosage of $350 \mathrm{Kg} / \mathrm{m} 3$, an $\mathrm{E} / \mathrm{C}$ ratio of 0.5 , a G/S ratio of 0,76 and a percentage in SP of 0.3 .
Natural pozzolana (PZ) and marble powder (PM) have been added as a mineral addition as a substitute for cement by mass in the proportions of $5 \%, 10 \%, 15 \%$, $20 \%$ mortar are shown in Table 3.

Table 2. Physical properties of alluvial sand.

\begin{tabular}{ll}
\hline Properties & Alluvial Sand \\
\hline Absolute specific gravity $\left(\mathrm{Kg} / \mathrm{m}^{3}\right)$ & 2,62 \\
Fineness Module & 2,45 \\
Sand equivalent (\%) & 88 \\
Water absorption (\%) & 0,51 \\
\hline
\end{tabular}

\subsection{Test method}

The workability of 27 mixtures was tested by a mini cone, the dimensions of which are a reduction of those of the Abrams cone (homothety ratio of two) according to the concrete equivalent mortar (CEM) method, and the flow time by the LCPC maniabilimeter. Several studies have shown that the slump value is necessary but not a sufficient measure to characterize the fundamental rheological properties of concrete. To this end, a coaxial rheometer was used to measure the rheological parameters of mortars, this rheometer has recently been validated for mortars and concretes [9].

Fresh CEM rheological behavior is considered similar to that of Bingham fluid, which is given by

$$
\tau=\tau_{0}+\mu \dot{\gamma}
$$

\section{Results and discussion}

\subsection{Mineral addition effect}

\subsubsection{Effect of natural pozzolana}

To evaluate the modifications induced by natural pozzolana on the concrete equivalent mortars in a standard environment, we tested 4 compositions of CEM made from natural pozzolana and one composition made without addition and taken as a control.

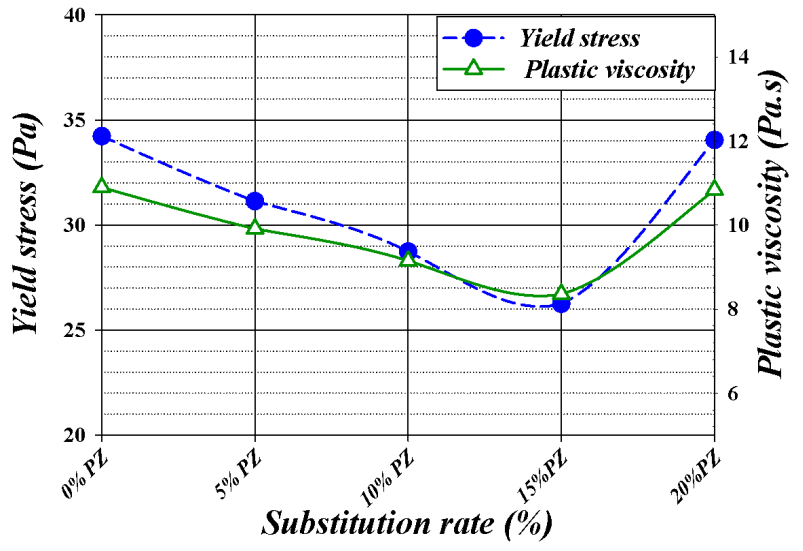

Fig. 3. Effect of $\mathrm{PZ}$ addition on CEM rheological parameters 
Figures 3 and 4 show natural pozzolana effect on CEM rheological behavior and the workability and flow time respectively. Note that the addition of $5 \% \mathrm{PZ}, 10 \% \mathrm{PZ}$ and $15 \% \mathrm{PZ}$ in the cement matrix improved the rheological parameters [1].

Table 1. Mixture proportions of the tested Concrete equivalent mortars

\begin{tabular}{|c|c|c|c|c|c|c|}
\hline Description & E & CPA & MP & $\mathbf{P Z}$ & Sable & SP \\
\hline Mixtures & $\left(\mathrm{Kg} / \mathrm{m}^{3}\right)$ & $\left(\mathrm{Kg} / \mathrm{m}^{3}\right)$ & $\left(\mathrm{Kg} / \mathrm{m}^{3}\right)$ & $\left(\mathrm{Kg} / \mathrm{m}^{3}\right)$ & $\left(\mathrm{Kg} / \mathrm{m}^{3}\right)$ & $(\%)$ \\
\hline $100 \% \mathrm{CPA}$ & 178.50 & 357 & 0 & & 986,12 & 0.3 \\
\hline $5 \% \mathrm{MP}$ & & 339.15 & 17.85 & & & \\
\hline $10 \% \mathrm{MP}$ & & 321.30 & 35.70 & & & \\
\hline $15 \% \mathrm{MP}$ & & 303.45 & 53.55 & & & \\
\hline $20 \% \mathrm{MP}$ & & 285.6 & 71.40 & & & \\
\hline $5 \% \mathrm{PZ}$ & 178.50 & 339.15 & & 17.85 & 986.12 & 0.3 \\
\hline $10 \% \mathrm{PZ}$ & & 321.30 & & 35.70 & & \\
\hline $15 \% \mathrm{PZ}$ & & 303.45 & & 53.55 & & \\
\hline $20 \% \mathrm{PZ}$ & & 285.6 & & 71.40 & & \\
\hline
\end{tabular}

However, beyond 15\%, pozzolana increased mortars yield stress and the viscosity seems to be due to pozzolana angular shape.

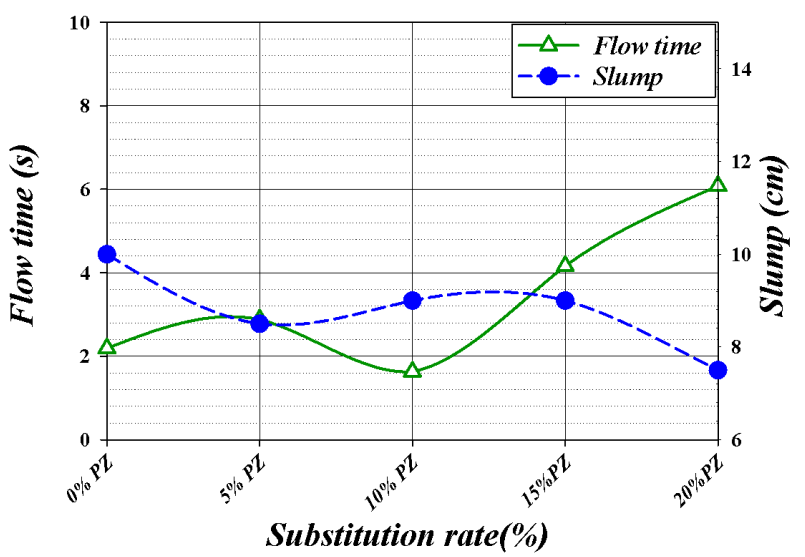

Fig. 4. Effect of PZ addition on CEM workability and flow time

At the same time, the presence of natural pozzolana as a cement replacement of $5 \%$ to $20 \%$ resulted in a slight decrease in the slump in the range of 1 to $2.5 \mathrm{~cm}$ (Figure 4). On the other hand, the addition of natural pozzolana as a substitute for cement has generally increased the flow time.

\subsubsection{Effect of marble powder}

Based on the experimental results presented graphically in figures ( 5 and 6 ), we found that the addition of marble powder as a substitute for cement is very effective both rheologically and workability in a standard environment. A good rheological behavior is ensured by the addition of marble powder to replace cement above $5 \%$. This is due to the diluting effect of inert marble powder.

At the same time, the variation in CEM slump as a function of the MP dosage presented in Figure (6).

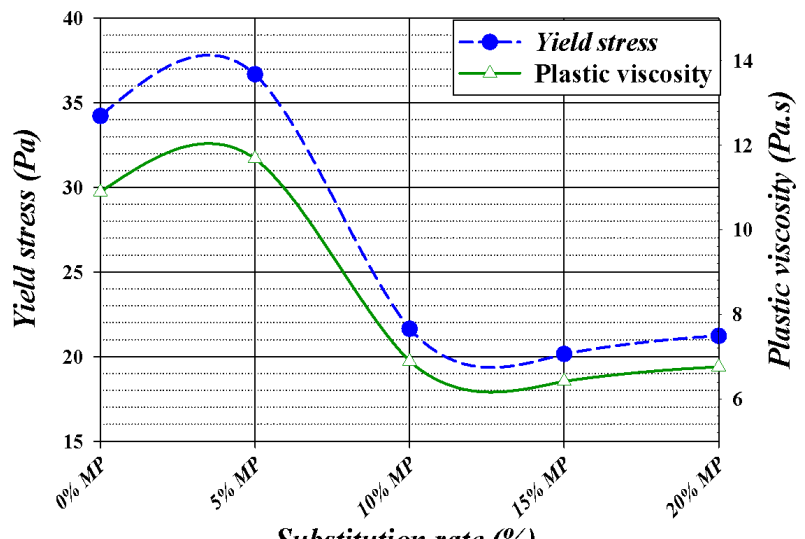

Fig. 5. Effect of MP addition on CEM rheological parameters 


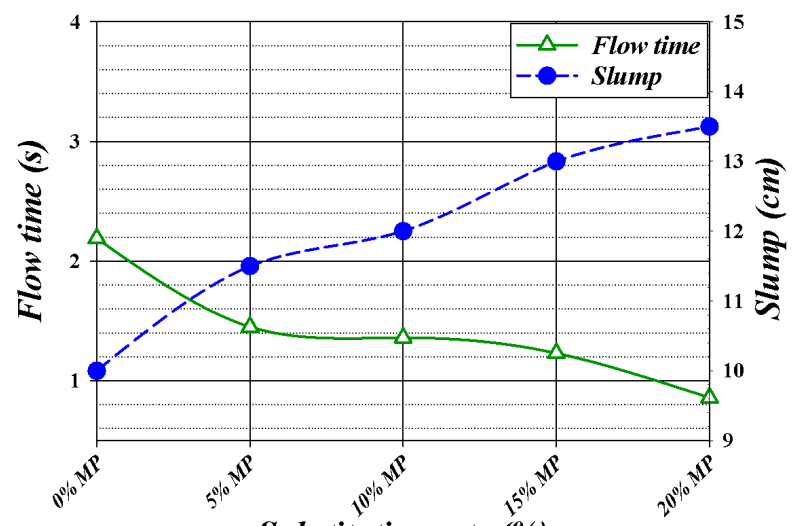

Substitution rate (\%)

Fig. 6. Effect of MP addition on CEM workability and flow time

It can be seen that marble powder has shown its ability to improve slump and flow time.

\subsection{Coupled effect temperature and addition on rheological behavior}

\subsubsection{Coupled effect of temperature and pozzolana}

Figures 7 and 8 describe the results obtained from tests on different CEM mixtures at different temperatures. They make it possible to judge the parameters of rheological behavior and also to observe that the changes in these parameters are quite similar whatever the temperature change and the substitution rate. It is noted that the coupled effect of the temperature and the pozzolana was beneficial to $30^{\circ} \mathrm{C}$ against a low temperature of $10^{\circ} \mathrm{C}$ negatively affected the yield stress and plastic viscosity.

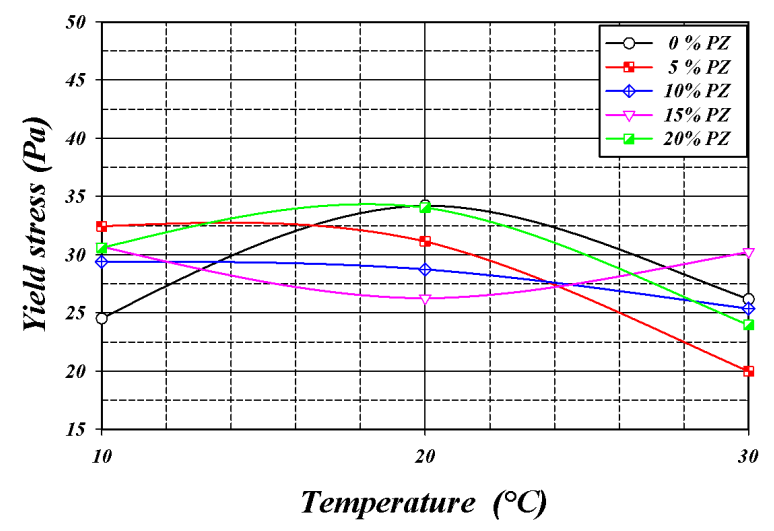

Fig. 7. Temperature effect on PZ- based CEM Yield stress

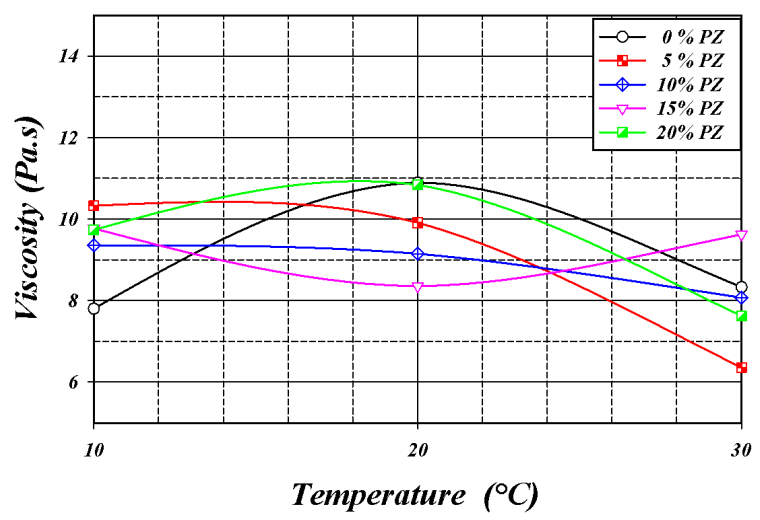

Fig. 8. Temperature effect on PZ- based CEM viscosity

Also Figures 9 and 10 show the variation in slump and flow time as a function of Pozzolana substitution rates, from which it can be seen that temperature has generally had a negative influence on workability and flow time.

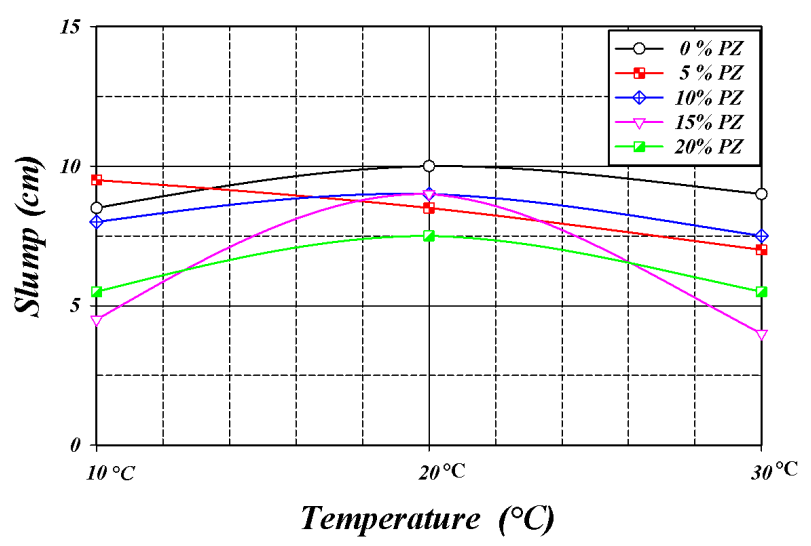

Fig. 9. Temperature effect on PZ- based CEM workability

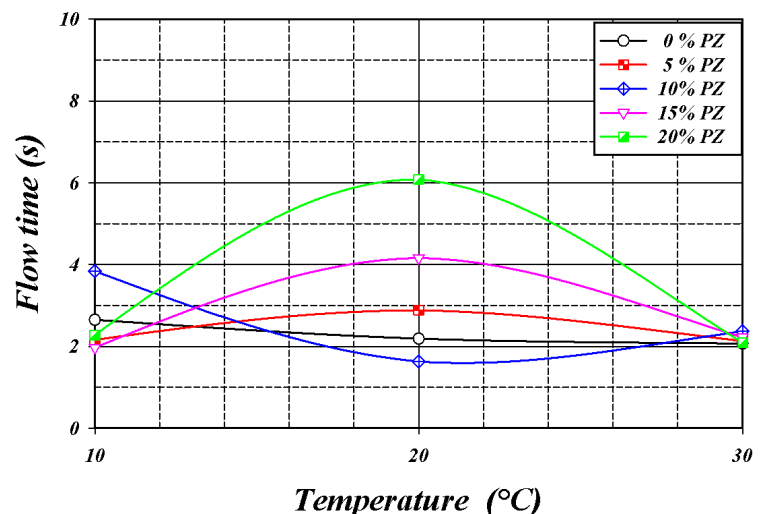

Fig. 10. Temperature effect on PZ- based CEM flow time

\subsubsection{Coupled effect of temperature and marble powder}

Figures 11 and 12 represent the temperature effect and marble powder On CEM yield stress and viscosity. 


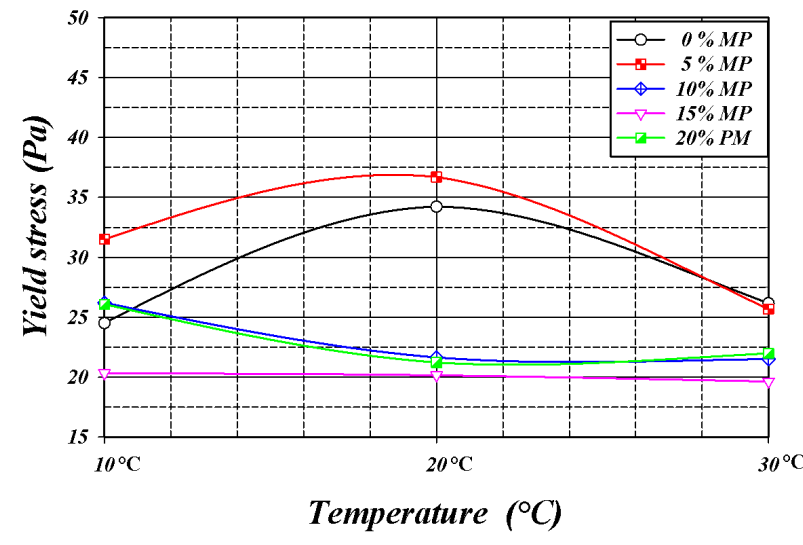

Fig. 11. Temperature effect on MP- based CEM Yield stress

From $20^{\circ} \mathrm{C}$ to $30^{\circ} \mathrm{C}$ the mixture with $10 \% \mathrm{MP}, 15 \% \mathrm{MP}$, and $20 \% \mathrm{MP}$ kept their stability while at $10^{\circ} \mathrm{C}$ the temperature increased the rheological parameters of the mixtures with 5\% PM, 10\% PM and 20\%PM.

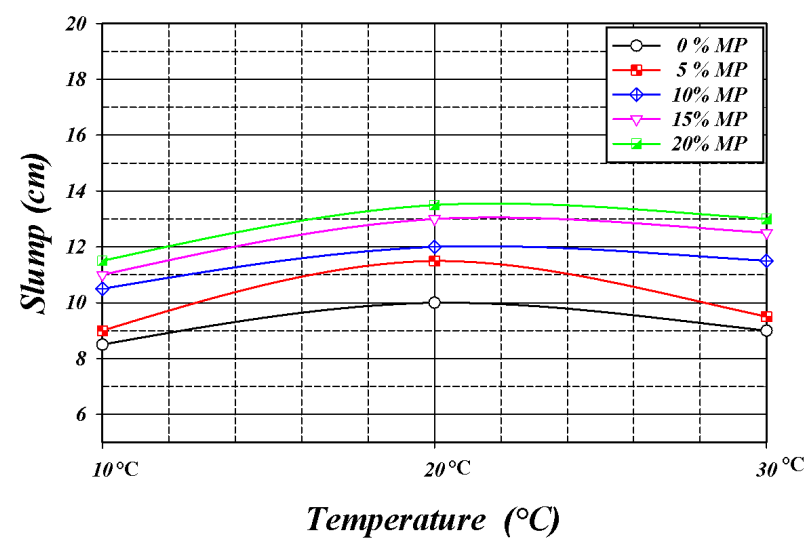

Fig. 12. Temperature effect on MP- based CEM workability

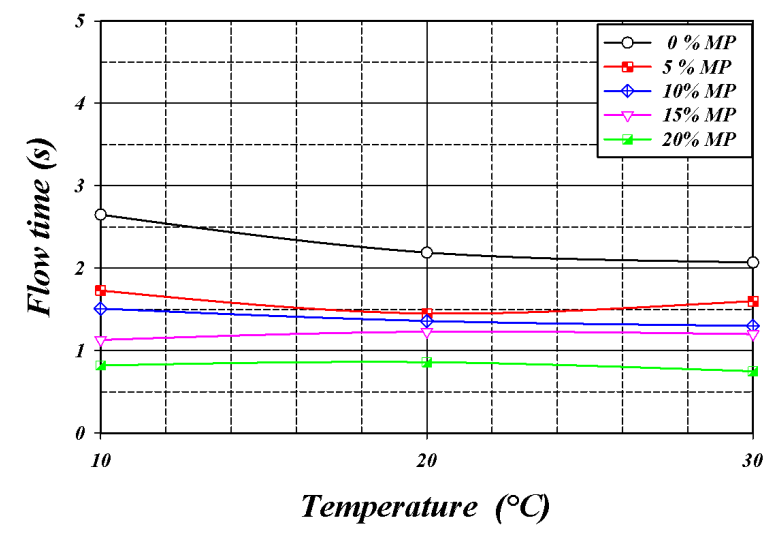

Fig. 13. Temperature effect on MP- based CEM flow time

Temperature effect on the slump and the flow time of the CEM based on the marble powder is shown in Figures 13 and $14 \mathrm{It}$ is noted that the temperature $10^{\circ} \mathrm{C}, 20^{\circ} \mathrm{C}$ and $30^{\circ} \mathrm{C}$ increased mortars workability and this due to marble powder dilution effect and the polycarboxylate superplasticizer effectiveness.

\section{Conclusion}

The main objective of this research work was the study of the coupled effect of mineral additions and temperature on concretes equivalent mortars (CEM) rheological properties with substitution rates of $5 \%$ to $20 \% \mathrm{PZ}$ and $\mathrm{MP}$ in a binary system at $10^{\circ} \mathrm{C}, 20^{\circ} \mathrm{C}$ and $30^{\circ} \mathrm{C}$. The results show that the:

- Concrete equivalent mortars of 5\% to $20 \% \mathrm{PZ}$ are beneficial for rheological parameters. However, at low temperatures, a loss of workability was observed.

- Concrete equivalent mortars based on $5 \%$ to $20 \% \mathrm{MP}$ at $10^{\circ} \mathrm{C}, 20^{\circ} \mathrm{C}$ and $30^{\circ} \mathrm{C}$ showed their efficiency both in terms of rheology and workability.

- The results show that the mechanism of the effect of temperature on the rheological behavior of eco-mortars is more complex than in the case of ordinary concrete. It is associated with the dose and type of superplasticizer and its resistance to temperature in terms of workability. It is also associated with the type of cement.

\section{References}

1. A.S.E. Belaidi, B. Benabed, H. Soualhi, J. Adh. Scie. \& Tech. Vol. 30, no. 3 (2016),

2. E. Dada, A.S.E. Belaidi, H. Soualhi, EL. Kadri, MATEC Web of Conferences 149, (2018).

3. F. Cassagnabère, P. Diederich, M. Mouret, G. Escadeillas, M. Lachemi, and al, Cem. \& Con. Com., vol. 37, (2013).

4. J. I. Escalante-Garcia, J.H. Tranchant, Cem. Con. Com., vol. 26, (2004).

5 K. Yamada, T. Yanagisawa, S. Hanehara, , $1^{\text {st }}$ International RILEM Symposium on SelfCompacting Concrete, (1999),

6. S. Hanehara, and K. Yamada, Cem. Con. Res., Vol. 38 No. 2, (2008).

7. , N. Ghafoori, and H. Diawara, Cons. Buil. Mate., Vol. 24, No. 6, (2010).

8. G. Cygon, J. Gołaszewski, M. P. Drewniok, Arch. of Civ. Engi., vol. 62, N 3 (2016),

9. H. Soualhi, El. Kadri, T. Ngo, A. Bouvet, F. Cussigh, Z. Tahar, J. Civ. Eng. Manag. (2016) 